\title{
PENGARUH FORMULA PUPUK MAJEMUK YANG BERBEDA TERHADAP PERTUMBUHAN KENTANG (Solanum tuberosum L) VARIETAS SANGKURIANG SECARA IN VITRO
}

\author{
Oleh : \\ Imas Kodariah*) \\ Sri Nur Widyastuti L**) \\ Pasetriyani $\left.\mathrm{W}^{* *}\right)$
}

\begin{abstract}
Abstrak
Media dengan formula yang seimbang sangatlah penting bagi pertumbuhan eksplan yang dikulturkan, oleh sebab itu penelitian ini bertujuan untuk mendapatkan alternatif formula pupuk majemuk sebagai pengganti formula media MS terhadap pertumbuhan kentang (Solanum tuberosum L.) varietas Sangkuriang secara in vitro. Penelitian dilaksanakan di Laboratorium kultur jaringan Balai Penelitian Tanaman Sayuran (BALITSA) Lembang, mulai bulan Mei sampai Juli tahun 2018. Metode penelitian yang digunakan adalah Percobaan dan Rancangan yang digunakan adalah Rancangan Acak Lengkap (RAL) dengan 9 (sembilan) perlakuan dan diulang sebanyak 3 (tiga) kali. Setiap perlakuan masing-masing berisi 2 planlet, dengan perlakuan $\mathrm{A}=$ Media MS 4,43 gram $/ \mathrm{l}, \mathrm{B}=$ Hyponex hijau 2 gram $/ \mathrm{l}, \mathrm{C}=$ Gandasil $\mathrm{D}$ 2 gram $/ 1, \mathrm{D}=$ Hyponex hijau 2 gram $/ 1+$ vitamin B complex 0,1 mg/ $1, \mathrm{E}=$ Hyponex hijau 2 gram $/ 1+$ air kelapa $300 \mathrm{ml} / 1, \mathrm{~F}=$ Hyponex hijau 2 gram $/ 1+$ vitamin B complex 0,1 mg/l + air kelapa $300 \mathrm{ml} / \mathrm{l}, \mathrm{G}=$ Gandasil D $2 \mathrm{gram} / 1+$ vitamin B complex 0,1 mg/l, H = Gandasil D 2 gram $/ 1+$ air kelapa $300 \mathrm{ml} / 1$, dan I = Gandasil D 2 gram $/ 1$ + vitamin B complex 0,1 mg/l + air kelapa $300 \mathrm{ml} / 1$. Pengamatan meliputi tinggi tanaman, jumlah buku, jumlah akar, panjang akar, dan vigor tanaman. Hasil penelitian menunjukkan bahwa Formula pupuk majemuk yang berbeda berpengaruh terhadap pertumbuhan kentang (Solanum tuberosum L.) varietas Sangkuriang secara in vitro. Alternatif formula pupuk majemuk pengganti formula media MS pertama ada pada perlakuan media $\mathrm{I}=$ Gandasil D 2 gram $/ 1+$ vitamin B complex $0,1 \mathrm{mg} / 1+$ air kelapa $300 \mathrm{ml} / 1$, alternatif formula kedua yaitu pada perlakuan $H=$ Gandasil D 2 gram $/ 1+$ air kelapa $300 \mathrm{ml} / 1$, dengan demikian perlakuan I dan $\mathrm{H}$ berpeluang baik terhadap pertumbuhan planlet karena telah mencapai keseimbangan formula untuk varietas Sangkuriang.
\end{abstract}

Kata kunci : Formula, Pupuk majemuk, Varietas sangkuriang, In vitro.

\begin{abstract}
Media with a balanced formula is very important for the growth of explants that are cultured, therefore this study aims to obtain an alternative compound fertilizer formula as a substitute for the MS media formula for the growth of potato (Solanumtuberosum L.) Sangkuriang variety in vitro. The research was carried out at the Tissue Laboratory of Vegetable Crops Research Institute (BALITS A) Lembang, from May to July 2018. The research method used was Experiment and the Design used was Completely Randomized Design (CRD) with 9 (nine) treatments and repeated 3 (three) times. Each treatment contained 2 planlets, with treatment $A=M S$ media 4.43 gram $/ l, B=$ green Hyponex 2 grams $/ l, C=$ Gandasil $D$ 2 grams $/ l, D=H y$ ponex green 2 grams $/ l+$ vitamin $B$ complex $0.1 \mathrm{mg} / l, E=$ green Hyponex 2 grams $/ l$ + coconut water $300 \mathrm{ml} / \mathrm{l}, \mathrm{F}=$ green Hyponex 2 grams $/ l+B$ complex vitamin $0.1 \mathrm{mg} / l+$ coconut water $300 \mathrm{ml} / \mathrm{l}, G=$ Gandasil D 2 grams $/ l+B$ vitamin complex $0.1 \mathrm{mg} / \mathrm{l}, H=$ Gandasil D 2 grams $/ l+$
\end{abstract}




coconut water $300 \mathrm{ml} / \mathrm{l}$, and I = Gandasil D 2 grams $/ l+$ vitamin B complex $0,1 \mathrm{mg} / \mathrm{l}+$ coconut water $300 \mathrm{ml} / \mathrm{l}$. Observations included plant height, number of books, number of roots, root length, and plant vigor. The results showed that different compound fertilizer formula had an effect on the growth of potato (Solanumtuberosum L.) Sangkuriang variety in vitro. Alternative formula for substitute compound fertilizer for the first MS media formula was on the media treatment $I=G$ andasil D $2 \mathrm{gram} / l+B$ complex vitamin $0.1 \mathrm{mg} / \mathrm{l}+$ coconut water $300 \mathrm{ml} / \mathrm{l}$, the second alternative formula was the treatment $H=$ Gandasil D 2 gram $/ l+$ coconut water $300 \mathrm{ml} / \mathrm{l}$, thus treatment I and H have a good chance of plantlet growth because it has reached the balance formula for Sangkuriang variety

Keys word: Formula, Compound fertilizer, Sangkuriang variety, In vitro

*) Alumni Faperta Universitas Bandung Raya

**) Dosen Tetap Faperta Universitas Bandung Raya 


\section{PENDAHULUAN}

Kentang (Solanum tuberosum L.) adalah salah satu tanaman sayuran termasuk famili Solanaceae yang dibudidayakan pada dataran tinggi. Kandungan karbohidrat dalam kentang menjadikan tanaman ini merupakan salah satu sumber pangan dunia, disamping mineral, protein, dan sejumlah vitamin esensial yang bermanfaat untuk kesehatan masyarakat (Rubatsky dan Yamaguchi, (1995) dalam Chris dan Agus, 2014).

Di Indonesia komoditas Kentang (Solanum tuberosum L.) termasuk salah satu komoditas penting yang mempunyai potensi dan prospek untuk mendukung program diversifikasi pangan (Prabaningrum dkk, 2014). Menurut Badan Pusat Statistik (2016) produksi kentang nasional dari tahun 2014-2016 mengalami penurunan, yaitu dari 1.347.815 ton menjadi 1.213.038 ton, salah satunya disebabkan oleh kurangnya ketersediaan benih kentang dan kurangnya ketahanan terhadap hama dan penyakit, terutama virus dan penyakit busuk daun.

$$
\text { Badan Penelitian dan }
$$

Pengembangan Daerah Provinsi Jawa Barat (BP2D) bekerja sama dengan BALITSA (Badan Penelitian Tanaman Sayuran) dan Balai Pengembangan Benih Kentang (BPBK) Pangalengan di bawah Dinas Tanaman Pangan dan Hortikultura, merilis dan mengembangkan dua varietas kentang baru yang toleran terhadap penyakit busuk daun.

Varietas baru tersebut telah terdaftar di Kementrian Pertanian pada tahun 2016, salah satu varietasnya adalah Sangkuriang. Varietas ini merupakan hasil persilangan antara varietas Atlantik dan Katahdin dan panen 100-110 hari. Varietas ini digunakan untuk produksi kentang, terutama keripik dan kentang goreng siap saji.

Untuk meningkatkan produksi, benih kentang harus bebas dari penyakit serta penyediaan benih dalam jumlah yang cukup dan tersedia tepat waktu. Hal itu dapat dilaksanakan dengan teknik kultur jaringan (in vitro), karena dengan teknik ini benih kentang dapat diperbanyak setiap waktu tanpa mengenal musim, dapat menghasilkan jumlah benih yang banyak dalam waktu yang singkat, tidak membutuhkan banyak tempat, juga terbebas dari pathogen.

Kultur jaringan adalah suatu metode untuk mengisolasi bagian tanaman seperti jaringan, organ ataupun embrio serta menumbuhkannya dalam kondisi steril sehingga bagian bagian tersebut mampu beregenerasi dan berdiferensiasi menjadi tanaman lengkap Winata (1987) dalam Zulkarnain (2009). Kultur jaringan kentang umumnya menggunakan teknik meristem dan setek. Teknik meristem dilakukan dengan cara mengisolasi bagian meristem pada pucuk tunas umbi kentang dan menumbuhkan pada media yang aseptik.

Schwan dan Schleiden (1838) dalam Zulkarnaen (2009) menyatakan bahwa sel-sel bersifat otonom, dan pada prinsipnya mampu beregenerasi menjadi tanaman lengkap. Teori inilah yang menjadi dasar Haberlandt pada awal abad ke-20 menyatakan bahwa jaringan tanaman dapat diisolasi dan dikultur hingga berkembang menjadi tanaman normal dengan melakukan manipulasi terhadap kondisi lingkungan dan nutrisinya.

Nutrisi yang mengandung unsur hara yang seimbang sangatlah penting bagi pertumbuhan eksplan yang dikulturkan, karena ketika eksplan dikulturkan akan mengalami perubahanperubahan pada jaringannya yang dinyatakan oleh Hartmann et al (1990) dalam Zulkarnain (2009) sebagai suatu "situasi krisis".

Kehilangan suplai air dan mineral mengakibatkan tekanan akar pada media kultur berkurang, sehingga menghambat pengambilan karbohidrat sebagai sumber makanan planlet. Kondisi ini dapat diatasi dengan restorasi suplai air, nutrisi dan zat pengatur tumbuh pada media (Schwabe,1984 dalam Zulkarnain, 2009) 
Penggunaan Murashige \& Skoog (selanjutnya MS) sebagai media tumbuh dalam perbanyakan in vitro telah banyak digunakan terutama untuk tanaman kentang. Media MS adalah media yang ditemukan oleh Murashige dan Skoog pada tahun 1962. Media MS mengandung unsur hara P.A (Pro analisis) dengan kemurnian yang sangat tinggi dan larutan ini telah dianalisis konsentrasinya secara kuantitatif di laboratorium tempatnya diproduksi. MS mengandung hara makro dan mikro seperti $\mathrm{CaCl}_{2}, \mathrm{KH}_{2} \mathrm{PO}_{4}$, $\mathrm{KNO}_{3}, \mathrm{MgSO}_{4}, \mathrm{NH}_{4} \mathrm{NO}_{3}, \mathrm{CoCl}_{2} \cdot 6 \mathrm{H}_{2} \mathrm{O}$, $\mathrm{CuSO}_{4} .5 \mathrm{H}_{2} \mathrm{O}, \mathrm{H}_{3} \mathrm{BO} 0_{3}, \mathrm{KI}, \mathrm{MnSO}_{4} .4 \mathrm{H}_{2} \mathrm{O}$, $\mathrm{Na}_{2} \mathrm{MoO}_{4} .2 \mathrm{H}_{2} \mathrm{O}, \mathrm{ZnSO}_{4} .7 \mathrm{H}_{2} \mathrm{O}, \mathrm{FeSO}_{4}$. $7 \mathrm{H}_{2} \mathrm{O}, \quad \mathrm{Na}_{2}$ EDTA, Thiamine HCL, Nicotianic acid, Pyridoxine HCL, Glycine, Myoinositol (Murashige \& Skoog, (1962) dalam Santoso dan Fatimah, 2003).

Umumnya kultur jaringan kentang menggunakan media MS (Murashige dan Skoog) namun harganya cukup mahal, sehingga perlu alternatif media lain yang mempunyai formulasi yang hampir sama dengan media MS, yaitu menggunakan pupuk majemuk dan kombinasi dengan bahan lain berupa pupuk majemuk Hyponex hijau, Gandasil D, air kelapa dan vitamin B complek.

Pada tanaman kentang supaya lebih efisien dengan pertumbuhan yang optimal perlu dilakukan penelitian mengenai media lain yang mempunyai unsur hara yang hampir sama dengan media MS yaitu dengan menggunakan media teknis berupa pupuk majemuk dan mengkombinasikan dengan bahan lain, bahan pembuatan media yang digunakan berupa pupuk majemuk hyponex hijau, gandasil D, air kelapa dan vitamin B complex.

Pupuk hyponex dan gandasil termasuk pupuk majemuk dengan unsur hara makro dan mikro lengkap mengandung $\mathrm{N}, \mathrm{P}, \mathrm{K}, \mathrm{S}, \mathrm{Mg}, \mathrm{Fe}, \mathrm{Zn}, \mathrm{Ca}$, $\mathrm{Co}, \mathrm{Mn}, \mathrm{Mo}, \mathrm{B}$ dan $\mathrm{Cu}$ yang hampir sama dengan komposisi media MS (Shintiavira dkk, 2014). Pupuk tersebut mempunyai kemurnian yang lebih rendah bila dibandingkan dengan unsur hara P.A
(Proanalis) yang memiliki kemurinan hingga $99,5 \%$, sehingga pemakaian pupuk majemuk harus tepat dan perlu dikombinasikan dengan unsur lain yaitu vitamin B complex dan air kelapa.

Vitamin berperan dalam katalitik pada sistem enzim dan dibutuhkan dalam jumlah yang sedikit. Vitamin B complex dari vitamin $\mathrm{B}$ complex IPI megandung Vitamin $\mathrm{B}_{1} \quad$ (tiamin), vitamin $\mathrm{B}_{2}$ (riboflavin), vitamin $\quad \mathrm{B}_{6} \quad$ (piridoksin), calcium penthathonate dan nicotinic acid (Shintiavira, 2014). Vitamin ini dibutuhkan tanaman untuk melakukan pertumbuhan dan perkembangannya secara normal, karena ketika tanaman tumbuh asupan vitamin menjadi berkurang, sehingga diperlukan penambahan vitamin dari luar.

Berdasarkan analisis hormon yang dilakukan oleh Savitri (2005, dalam Djamhuri, 2011 dikutip kembali oleh Darlina dkk, 2016) air kelapa muda mengandung hormon giberelin (GA3, GA5, GA7), sitokinin (kinetin, zeatin), dan auksin (IAA). Menurut Kristina dan Syahid (2012) dalam Darlina, dkk (2016) air kelapa juga mengandung kadar kalium sebanyak 14,11 mg/100 ml, kalsium sebanyak $24,67 \mathrm{mg} / 100 \mathrm{ml}$, dan nitrogen sebanyak 43,00 mg/100 ml pada air kelapa muda. Penelitian yang dilakukan oleh Nadapdap (2000) menunjukkan bahwa pupuk daun hyponex 1,5 g/l dan air kelapa $300 \mathrm{ml} / \mathrm{l}$ dapat digunakan sebagai pengganti media MS pada perbanyakan kentang secara in vitro.

Hasil penelitian yang dilakukan Shintiavira dkk (2014) tentang kombinasi vitamin $\mathrm{B}$ complex menunjukkan bahwa 3 $\mathrm{g} / 1$ hyponex $+0,1 \mathrm{mg} / 1$ vitamin $\mathrm{B}$ kompleks teknis + 0,1 $\mathrm{mg} / \mathrm{l}$ IAA merupakan media generik paling sesuai untuk menggantikan media MS dalam kultur in vitro Krisan. Hal ini karena Vitamin B complex terdiri dari vitamin B1, B2, B6, calcium penthathonate dan nicotianic acid. Menurut hasil analisis ekonomi yang dilakukan oleh Shintiavira pada tahun 2012 untuk kultur in vitro krisan, pemanfaatan media generik dapat 
menghemat hingga 35\% dibandingkan dengan menggunakan media MS, disamping lebih murah bahan mudah di dapat di toko sarana produksi pertanian.

Berdasarkan uraian di atas dapat diidentifikasikan permasalahanya yaitu apakah formula pupuk majemuk yang berbeda berpengaruh terhadap pertumbuhan kentang (Solanum tuberosum L.) varietas Sangkuriangsecara in vitro dan pada formula pupuk majemuk manakah yang dapat dijadikan alternatif pengganti formula media MS untuk pertumbuhan kentang (Solanum tuberosum L.) varietas Sangkuriang secara in vitro. Sedangka tujuan penelitian ini untuk mendapatkan alternatif formula pupuk majemuk sebagai pengganti formula media MS terhadap pertumbuhan kentang (Solanum tuberosum L.) varietas Sangkuriang secara in vitro .

\section{Kegunaan Penelitian}

Penelitian ini dapat digunakan sebagai bahan informasi dan menambah pengetahuan bagi peneliti khususnya dan

masyarakat pada umumnya mengenai pengaruh formula pupuk majemuk yang berbeda terhadap pertumbuhan kentang (Solanum tuberosum L.) varietas sangkuriang secara in vitro.

\section{METODE PENELITIAN}

\section{Waktu dan Tempat}

Penelitian dilaksanakan di

Laboratorium kultur jaringan Balai Penelitian Tanaman Sayuran (BALITSA) Jln. Tangkuban Perahu No 517, kecamatan Lembang Bandung, Jawa Barat. Penelitian berlangsung mulai bulan Mei 2018 sampai bulan Juli 2018.

Metode penelitian
digunakan adalah Percobaan dan
Rancangan yang digunakan adalah
Rancangan Acak Lengkap (RAL) dengan
9 (sembilan) perlakuan dan diulang
sebanyak 3 (tiga) kali. Setiap perlakuan
masing - masing berisi 2 planlet, dengan
perlakuan sebagai berikut:

Tabel 1. Formula Pupuk Majemuk

\begin{tabular}{cl}
\hline Perlakuan & \multicolumn{1}{c}{ Formula Pupuk Majemuk } \\
\hline A & Media MS 4,43 g/l \\
B & Hyponex hijau $2 \mathrm{~g} / 1$ \\
$\mathrm{C}$ & Gandasil D $2 \mathrm{~g} / 1$ \\
$\mathrm{D}$ & Hyponex hijau $2 \mathrm{~g} / \mathrm{l}+$ vitamin B complex $0,1 \mathrm{mg} / \mathrm{l}$ \\
$\mathrm{E}$ & Hyponex hijau $2 \mathrm{~g} / 1+$ air kelapa $300 \mathrm{ml} / 1$ \\
$\mathrm{~F}$ & Hyponex hijau2 $\mathrm{g} / 1+$ vitamin B complex $0,1 \mathrm{mg} / 1+$ air kelapa $300 \mathrm{ml} / 1$ \\
$\mathrm{G}$ & Gandasil D $2 \mathrm{~g} / 1+$ vitamin B complex $0,1 \mathrm{mg} / 1$ \\
$\mathrm{H}$ & Gandasil D $2 \mathrm{~g} / 1+$ air kelapa $300 \mathrm{ml} / 1$ \\
$\mathrm{I}$ & Gandasil D $2 \mathrm{~g} / 1+$ vitamin B complex $0,1 \mathrm{mg} / 1+$ air kelapa $300 \mathrm{ml} / 1$ \\
\hline
\end{tabular}

\section{Pelaksanaan Percobaan}

\section{Sterilisasi alat, media dan lingkungan kerja}

Sterilisasi alat dilakukan dengan cara mencuci dengan larutan sabun kemudian dibilas dengan air bersih yang mengalir sampai bersih, lalu di sterilisasi menggunakan autoklaf dengan suhu $121^{\circ}$ C selama 60 menit, kemudian dikeringkan selama 30 menit, sedangkan untuk media tanam di autoklaf selama 30 menit (tergantung volume bahan yang disterilkan).
Sterilisasi lingkungan kerja dimulai dengan membersihkan laminar, dengan cara lampu UV (Ultraviolet) dinyalakan selama 30 menit, lalu lampu biasa dan blower pada laminar dinyalakan, semua permukaan laminar disemprot alkohol $70 \%$ dan dilap memakai kain tisu, langkah ini dilakukan sebanyak 3 kali pada saat akan memulai penanaman dan setelah melakukan penanaman. 


\section{Pembuatan media tanam}

Media Murashige \& Skoog (MS), hyponex hijau, gandasil $\mathrm{D}$, dan vitamin $\mathrm{B}$ complex ditimbang sesuai dengan perlakuan A, B, C, D, E, F, G, H dan I, sedangkan air kelapa ditambahkan pada perlakuan E, F, H dan I, kemudian masing-masing perlakuan ditambahkan gula $40 \mathrm{~g} / \mathrm{l}$, pH diatur sampai 5,7 dengan menambahkan asam (HCL 1\%) atau basa $(\mathrm{NaOH} 1 \%)$ kemudian semua perlakuan ditambah agar-agar $6 \mathrm{~g} / \mathrm{l}$.

Larutan dipanaskan dan dituangkan kedalam botol jam yang steril sebanyak \pm $25 \mathrm{ml} /$ botol, penutupan botol menggunakan plastik bening dan diikat karet lalu di beri label sesuai perlakuan. Semua perlakuan di sterilisasi dengan autoklaf selama 30 menit dan disimpan di ruang penyimpanan selama 3 - 7 hari.

\section{Penanaman planlet (subkultur)}

Penanaman dilakukan di ruang laminar, bahan tanam yang digunakan berupa planlet Sangkuriang yang berumur 2 bulan setelah subkultur.9 Penanaman dimulai dengan mensterilisasi kembali alat dengan cara mencelupkan ke larutan alkohol $95 \%$ dan mendekatkan alat ke api bunsen, hal ini dilakukan sebelum dan sesudah penyetekan. Setiap botol ditanami 2 setek buku tunggal.

\section{Pengamatan}

Pengamatan utama adalah pengamatan yang diamati dan datanya dianalisis secara statistika, yaitu meliputi :

1.

inggi planlet diukur dari pangkal buku daun sampai titik tumbuh dari setiap perlakuan diamati mulai minggu ke 1,3 dan 5 setelah subkultur.

2.

umlah buku planlet, banyaknya tempat keluarnya daun pada batang, dihitung dari pangkal sampai ujung tanaman diamati mulai minggu ke 1, 3 dan 5 setelah subkultur.

3.

umlah akar planlet ialah banyaknya akar yang muncul pada planlet dari setiap perlakuan dengan interval diamati mulai minggu ke 1, 3 dan 5 setelah subkultur.

4.

anjang akar planlet diukur dari pangkal akar sampai akar terpanjang dari setiap perlakuan diukur dua kali yaitu pada minggu ke 1 dan

5.

igor tanaman dari semua perlakuan diberi nilai dari 1 sampai 9, dengan nilai 1 sangat buruk dan nilai 9 sangat baik.

\section{HASIL DAN PEMBAHASAN}

\section{Tinggi Planlet}

Dari data hasil pengamatan yang disajikan pada Tabel 2, menunjukkan bahwa pada minggu ke 1 dan ke 3 nilai tertinggi ada pada perlakuan $\mathrm{G}=$ Gandasil D + vitamin B complex diikuti oleh perlakuan $\mathrm{I}=$ Gandasil $\mathrm{D}+$ vitamin $\mathrm{B}$ complex + air kelapa dan $\mathrm{A}=$ Media MS, sedangkan tanaman terpendek ada pada perlakuan $\mathrm{B}=$ Hyponex hijau. Hal ini disebabkan karena media gandasil dan media MS mempunyai nitrogen yang lebih banyak daripada hyponex. Sesuai dengan pendapat Smith (1977) dalam Nadapdap (2000) bahwa penggunaan nitrogen yan'g tinggi dapat meningkatkan kegiatan meristem ujung batang dan tunas lateral yang menyebabkan meningkatnya tinggi tanaman.
PENGARUH FORMULA PUPUK MAJEMUK

YANG BERBEDA TERHADAP

PERTUMBUHAN KENTANG (Solanum

tuberosum L) VARIETAS SANGKURIANG

SECARA IN VITRO
IMAS KODARIAH, SRI NUR WIDYASTUTI L dan PASETRIYANI W 
Tabel 2. Pengaruh Formula Pupuk Majemuk Yang Berbeda Terhadap Tinggi Planlet Pada Minggu Ke 1, 3 Dan 5 Setelah Subkultur

\begin{tabular}{|c|c|c|c|c|}
\hline & \multirow{3}{*}{ Perlakuan } & \multicolumn{3}{|c|}{ Tinggi planlet $(\mathrm{cm})$} \\
\hline & & \multicolumn{3}{|c|}{ Minggu ke - } \\
\hline & & 1 & 3 & 5 \\
\hline $\mathrm{A}=$ & Media MS 4,43 g/l & $0,57 \mathrm{bc}$ & $4,83 \mathrm{bc}$ & $8,82 \mathrm{bc}$ \\
\hline $\mathrm{B}=$ & Hyponex hijau $2 \mathrm{~g} / 1$ & $0,05 \mathrm{a}$ & $0,63 \mathrm{a}$ & $2,33 \mathrm{a}$ \\
\hline$C=$ & Gandasil D $2 \mathrm{~g} / 1$ & $0,50 \mathrm{abc}$ & $5,37 \mathrm{bc}$ & $10,42 \mathrm{~cd}$ \\
\hline $\mathrm{D}=$ & Hyponex hijau $2 \mathrm{~g} / 1+$ vitamin B complex $0,1 \mathrm{mg} / 1$ & $0,43 \mathrm{abc}$ & $1,42 \mathrm{a}$ & $1,45 \mathrm{a}$ \\
\hline $\mathrm{E}=$ & Hyponex hijau $2 \mathrm{~g} / 1+$ air kelapa $300 \mathrm{ml} / 1$ & $0,55 \mathrm{bc}$ & $1,73 \mathrm{a}$ & $7,67 \mathrm{bc}$ \\
\hline $\mathrm{F}=$ & $\begin{array}{l}\text { Hyponex hijau } 2 \mathrm{~g} / 1+\text { vitamin B complex } 0,1 \mathrm{mg} / 1+ \\
\text { air kelapa } 300 \mathrm{ml} / 1\end{array}$ & $0,25 \mathrm{ab}$ & $1,10 \mathrm{a}$ & $8,65 \mathrm{bc}$ \\
\hline$G=$ & Gandasil D $2 \mathrm{~g} / 1+$ vitamin B complex 0,1 mg/1 & $0,78 \mathrm{c}$ & $5,92 \mathrm{c}$ & $6,95 b$ \\
\hline $\mathrm{H}=$ & Gandasil D $2 \mathrm{~g} / 1+$ air kelapa $300 \mathrm{ml} / 1$ & $0,40 \mathrm{abc}$ & $1,65 \mathrm{a}$ & $12,08 \mathrm{~d}$ \\
\hline $\mathrm{I}=$ & $\begin{array}{l}\text { Gandasil D } 2 \mathrm{~g} / 1 \text { + vitamin B complex } 0,1 \mathrm{mg} / 1+\text { air } \\
\text { kelapa } 300 \mathrm{ml} / 1\end{array}$ & $0,62 \mathrm{bc}$ & $3,10 \mathrm{ab}$ & $12,70 \mathrm{~d}$ \\
\hline
\end{tabular}

Keterangan: Nilai rata-rata yang ditandai huruf yang sama pada kolom yang sama tidak berbeda nyata pada uji Duncan 5\%.

Pada minggu ke 5 nilai tertinggi pada perlakuan $\mathrm{I}=$ Gandasil $\mathrm{D}+$ vitamin $\mathrm{B}$ complex + air kelapa dan perlakuan $\mathrm{H}$ = Gandasil D + air kelapa. Di dalam gandasil juga terdapat unsur S, dan Mo yang tidak terdapat pada hyponex. Unsur $\mathrm{S}$ berfungsi sebagai aktivator, dan Mo sebagai pengikat Nitrogen yang dikombinasikan dengan vitamin B complex yang berfungsi untuk mempercepat pembelahan sel dan memacu proses keluar tunas.

Hormon giberelin pada air kelapa diduga dapat memacu pertumbuhan dan pemanjangan pucuk dan batang, sehingga komposisi unsur hara yang dibutuhkan tanaman menjadi seimbang, sehingga tanaman menjadi lebih cepat tinggi daripada perlakuan lainnya.

\section{Jumlah Buku Planlet}

Berdasarkan hasil pengamatan yang disajikan pada tabel 3, pada minggu ke 5 jumlah buku terbanyak ada pada perlakuan $\mathrm{I}=$ Gandasil $\mathrm{D}+\operatorname{vitamin} \mathrm{B}$ complex + air kelapa, hal ini diduga karena media MS dan gandasil memiliki unsur $\mathrm{N}$ yang lebih banyak daripada hyponex, karena $\mathrm{N}$ diperlukan untuk pembentukan pertumbuhan bagian vegetatif tanaman terutama daun. Dengan penambahan vitamin B complex, hormon giberelin dan sitokinin pada air kelapa berperan dalam memacu pertumbuhan tumbuhan utuh, pemanjangan batang, dan memacu pemanjangan pucuk-pucuk tanaman, sehingga jumlah daun meningkat 
Tabel 3. Pengaruh Formula Pupuk Majemuk Yang Berbeda Terhadap Jumlah Buku Planlet Pada Minggu Ke 1, 3 Dan 5 Setelah Subkultur

\begin{tabular}{|c|c|c|c|}
\hline \multirow{3}{*}{ Perlakuan } & \multicolumn{3}{|c|}{ Jumlah buku } \\
\hline & \multicolumn{3}{|c|}{ Minggu ke - } \\
\hline & 1 & 3 & 5 \\
\hline $\mathrm{A}=$ Media MS 4,43 g/1 & $0,58 \mathrm{a}$ & $4,67 \mathrm{c}$ & $10,50 \mathrm{de}$ \\
\hline $\mathrm{B}=$ Hyponex hijau $2 \mathrm{~g} / 1$ & $0,00 \mathrm{a}$ & $0,50 \mathrm{a}$ & $2,92 \mathrm{a}$ \\
\hline $\mathrm{C}=$ Gandasil D $2 \mathrm{~g} / 1$ & $0,42 \mathrm{a}$ & $4,67 \mathrm{c}$ & $10,63 \mathrm{de}$ \\
\hline $\mathrm{D}=$ Hyponex hijau $2 \mathrm{~g} / 1+$ vitamin $\mathrm{B}$ complex $0,1 \mathrm{mg} / 1$ & $0,50 \mathrm{a}$ & $2,50 \mathrm{~b}$ & $4,00 \mathrm{ab}$ \\
\hline $\mathrm{E}=$ Hyponex hijau $2 \mathrm{~g} / 1+$ air kelapa $300 \mathrm{ml} / 1$ & $0,42 \mathrm{a}$ & $2,42 \mathrm{~b}$ & $7,50 \mathrm{~cd}$ \\
\hline $\mathrm{F}=\begin{array}{l}\text { Hyponex hijau } 2 \mathrm{~g} / \mathrm{l}+\text { vitamin B complex } 0,1 \mathrm{mg} / 1+\text { air } \\
\text { kelapa } 300 \mathrm{ml} / 1\end{array}$ & $0,00 \mathrm{a}$ & $1,83 \mathrm{ab}$ & $6,83 \mathrm{bc}$ \\
\hline $\mathrm{G}=$ Gandasil D $2 \mathrm{~g} / 1+$ vitamin B complex $0,1 \mathrm{mg} / 1$ & $0,50 \mathrm{a}$ & $4,33 \mathrm{c}$ & 9,67 cde \\
\hline $\mathrm{H}=$ Gandasil D $2 \mathrm{~g} / \mathrm{l}+$ air kelapa $300 \mathrm{ml} / \mathrm{l}$ & $0,42 \mathrm{a}$ & $1,83 \mathrm{ab}$ & 9,50 cde \\
\hline $\begin{aligned} \mathrm{I}= & \text { Gandasil D } 2 \mathrm{~g} / \mathrm{l}+\text { vitamin B complex } 0,1 \mathrm{mg} / 1 \\
& + \text { air kelapa } 300 \mathrm{ml} / 1\end{aligned}$ & $0,42 \mathrm{a}$ & $2,58 \mathrm{~b}$ & $13,00 \mathrm{e}$ \\
\hline
\end{tabular}

Keterangan: Nilai rata-rata yang ditandai huruf yang sama pada kolom yang sama tidak berbeda nyata pada uji Duncan 5\%.

\section{Jumlah Akar Planlet}

Dari Tabel 4. Dapat terlihat bahwa pada minggu ke 3 jumlah akar terbanyak ada pada perlakuan D dan E, sedangkan minggu ke 5 akar terbanyak ada pada perlakuan $\mathrm{F}=$ Hyponex hijau 2 $\mathrm{g} / \mathrm{l}+$ vitamin B complex $0,1 \mathrm{mg} / \mathrm{l}+$ air kelapa $300 \mathrm{ml} / \mathrm{l}$, hal ini diduga disebabkan hyponex mengandung unsur $\mathrm{P}$ dan $\mathrm{K}$ yang lebih banyak dibanding MS dan gandasil, $\mathrm{P}$ berfungsi untuk memacu pertumbuhan perakaran, dan $\mathrm{K}$ untuk meningkatkan jumlah akar tanamam.

Tabel 4. Pengaruh Formula Pupuk Majemuk Yang Berbeda Terhadap Jumlah Akar Planlet Pada Minggu Ke 1, 3 Dan 5 Setelah Subkultur

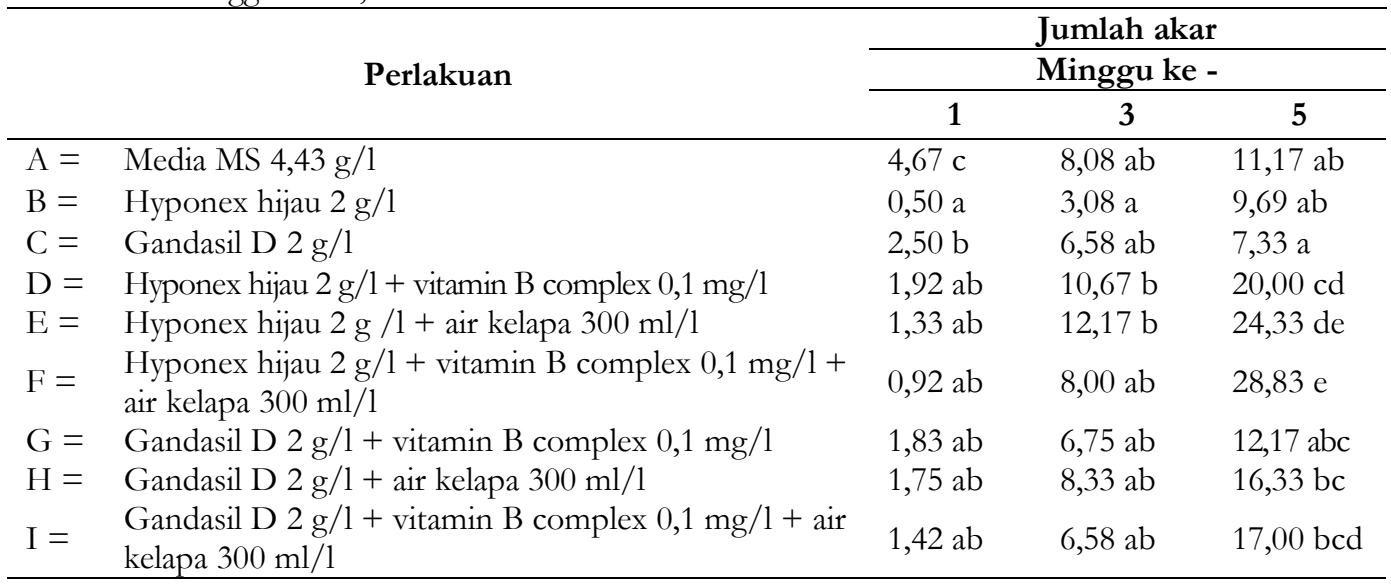

Keterangan : Nilai rata-rata yang ditandai huruf yang sama pada kolom yang sama tidak berbeda nyata pada uji Duncan 5\%. 


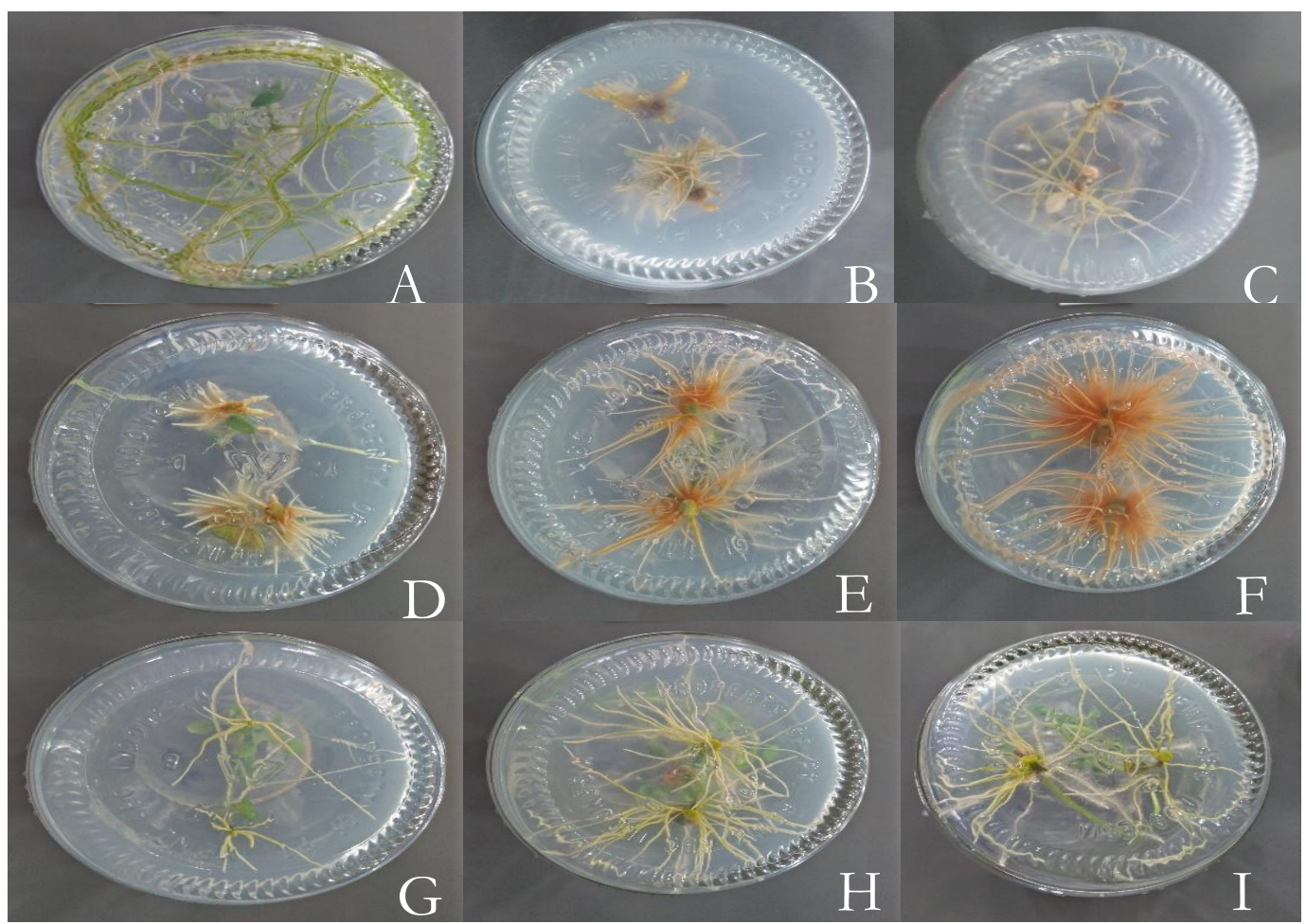

Gambar 1. Penampakan akar planlet kentang varietas Sangkuriang pada minggu ke 5. (A) Media MS 4,43 g/l, (B) Hyponex hijau $2 \mathrm{~g} / \mathrm{l}$, (C) gandasil $2 \mathrm{~g} / 1$ (D) Hyponex hijau $2 \mathrm{~g} / 1+$ vitamin B complex 0,1 mg/ l, (E) Hyponex hijau $2 \mathrm{~g} / 1+$ air kelapa $300 \mathrm{ml} / 1$, (F) Hyponex hijau $2 \mathrm{~g} / 1$ + vitamin B complex 0,1 mg/l + air kelapa $300 \mathrm{ml} / \mathrm{l}$, (G) Gandasil D $2 \mathrm{~g} / \mathrm{l}+$ vitamin B complex 0,1 mg/l, (H) Gandasil D $2 \mathrm{~g} / \mathrm{l}+$ air kelapa $300 \mathrm{ml} / \mathrm{l}$, (I) Gandasil D $2 \mathrm{~g} / \mathrm{l}+$ vitamin B complex 0,1 mg/l + air kelapa $300 \mathrm{ml} / 1$. (Dokumen pribadi. Balitsa.2018).

Vitamin B1 pada vitamin B complex berfungsi memperbaiki akar, dan hormon auksin, air kelapa berfungsi menstimulasi pembentukan dan perkembangan akar, sehingga terjadi akumulasi unsur hara di perakaran tanaman. Gambar perakaran planlet disajikan pada Gambar 1.

\section{Panjang Akar Planlet}

Berdasarkan hasil pengamatan yang disajikan pada Tabel 5, perlakuan media $\mathrm{A}=\mathrm{MS}$ menunjukan pertambahan panjang akar yang meningkat setiap minggu dan menempati nilai tertinggi diantara perlakuan lainnya, dan nilai panjang akar kedua ada pada perlakuan I $=$ Gandasil D + vitamin B complex + air kelapa dan $\mathrm{F}=$ Hyponex hijau + vitamin B complex + air kelapa, sedangkan akar terpendek pada perlakuan D = Hyponex hijau + vitamin B complex.
PENGARUH FORMULA PUPUK MAJEMUK YANG BERBEDA TERHADAP PERTUMBUHAN KENTANG (Solanum tuberosum L) VARIETAS SANGKURIANG SECARA IN VITRO
IMAS KODARIAH, SRI NUR WIDYASTUTI L dan PASETRIYANI W 
Tabel 5. Pengaruh Formula Pupuk Majemuk Yang Berbeda Terhadap Panjang Akar Planlet Pada Minggu Ke 1 Dan 5 Setelah Subkultur

\begin{tabular}{|c|c|c|c|}
\hline & \multirow{2}{*}{ Perlakuan } & \multicolumn{2}{|c|}{$\begin{array}{c}\text { Panjang akar }(\mathrm{cm}) \\
\text { Minggu ke - }\end{array}$} \\
\hline & & 1 & 5 \\
\hline $\mathrm{A}=$ & Media MS 4,43 g/l & $1,21 \mathrm{~b}$ & $14,98 \mathrm{e}$ \\
\hline $\mathrm{B}=$ & Hyponex hijau $2 \mathrm{~g} / 1$ & $0,10 \mathrm{a}$ & $1,16 \mathrm{ab}$ \\
\hline $\mathrm{C}=$ & Gandasil D 2 g/l & $0,18 \mathrm{a}$ & $1,85 \mathrm{abc}$ \\
\hline $\mathrm{D}=$ & Hyponex hijau $2 \mathrm{~g} / 1+$ vitamin B complex $0,1 \mathrm{mg} / 1$ & $0,45 \mathrm{a}$ & $0,98 \mathrm{a}$ \\
\hline $\mathrm{E}=$ & Hyponex hijau 2 g /1 + air kelapa 300 ml/1 & $0,55 \mathrm{a}$ & $2,52 \mathrm{abcd}$ \\
\hline $\mathrm{F}=$ & Hyponex hijau $2 \mathrm{~g} / \mathrm{l}+$ vitamin B complex 0,1 mg/l + air kelapa $300 \mathrm{ml} / 1$ & $0,47 \mathrm{a}$ & $4,38 \mathrm{~d}$ \\
\hline$G=$ & Gandasil D $2 \mathrm{~g} / 1+$ vitamin B complex $0,1 \mathrm{mg} / 1$ & $0,44 \mathrm{a}$ & $3,00 \mathrm{bcd}$ \\
\hline $\mathrm{H}=$ & Gandasil D $2 \mathrm{~g} / 1+$ air kelapa $300 \mathrm{ml} / 1$ & $0,39 \mathrm{a}$ & $3,52 \mathrm{~cd}$ \\
\hline $\mathrm{I}=$ & Gandasil D $2 \mathrm{~g} / \mathrm{l}+$ vitamin B complex 0,1 mg/l + air kelapa $300 \mathrm{ml} / 1$ & $0,53 \mathrm{a}$ & $4,38 \mathrm{~d}$ \\
\hline
\end{tabular}

Keterangan: Nilai rata-rata yang ditandai huruf yang sama pada kolom yang sama tidak berbeda nyata pada uji Duncan $5 \%$.

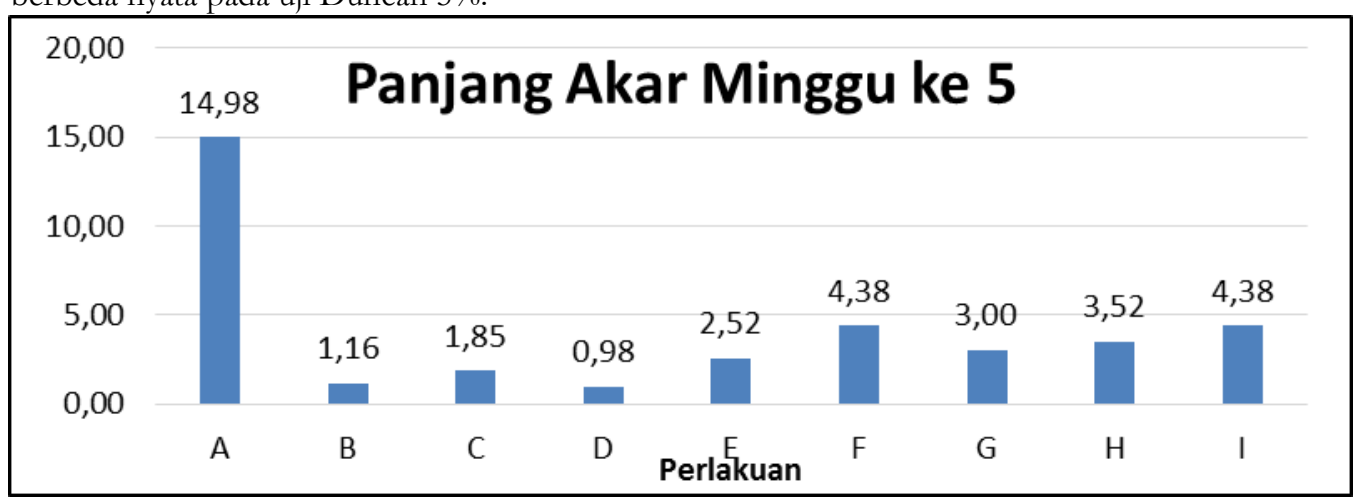

Gambar 2. Histogram panjang akar minggu ke 5

Berdasarkan histogram yang disajikan pada Gambar 2, perlakuan media MS mempunyai akar terpanjang karena memiliki unsur $\mathrm{N}$ untuk pembentukan perakaran, $\mathrm{K}$ memacu pertumbuhan perakaran dan $\mathrm{Ca}$ yang lebih banyak daripada perlakuan lain sehingga berpengaruh terhadap pemanjangan akar planlet. Pada perlakuan lain dengan unsur $\mathrm{Ca}$ yang lebih sedikit dapat mengakibatkan akar tidak mampu memanjang dengan cepat.

\section{Vigor Planlet}

Vigor merupakan kekuatan tumbuh untuk menjadi tanaman yang normal dalam keadaan lingkungan atau media yang kurang optimal, vigor dapat mencerminkan kondisi pertumbuhan dalam penilaian adaptasi mengenai kecocokan dalam lingkungan dan medianya.

Vigor ini dapat dilihat secara visual dari aspek pertumbuhannya yang meliputi tinggi tanaman, jumlah buku, jumlah akar, panjang akar dan warna daun. Gambar planlet disajikan pada Gambar 3. Vigor dari masing-masing planlet diberikan nilai dari 1 sampai 9, dengan nilai $1=$ sangat buruk, 3=buruk, 5=sedang, 7=baik dan nilai 9=sangat baik (CIP, 2007) dalam Kusmana, 2012).
PENGARUH FORMULA PUPUK MAJEMUK YANG BERBEDA TERHADAP PERTUMBUHAN KENTANG (Solanum tuberosum L) VARIETAS SANGKURIANG SECARA IN VITRO
IMAS KODARIAH, SRI NUR WIDYASTUTI L dan PASETRIYANI W 


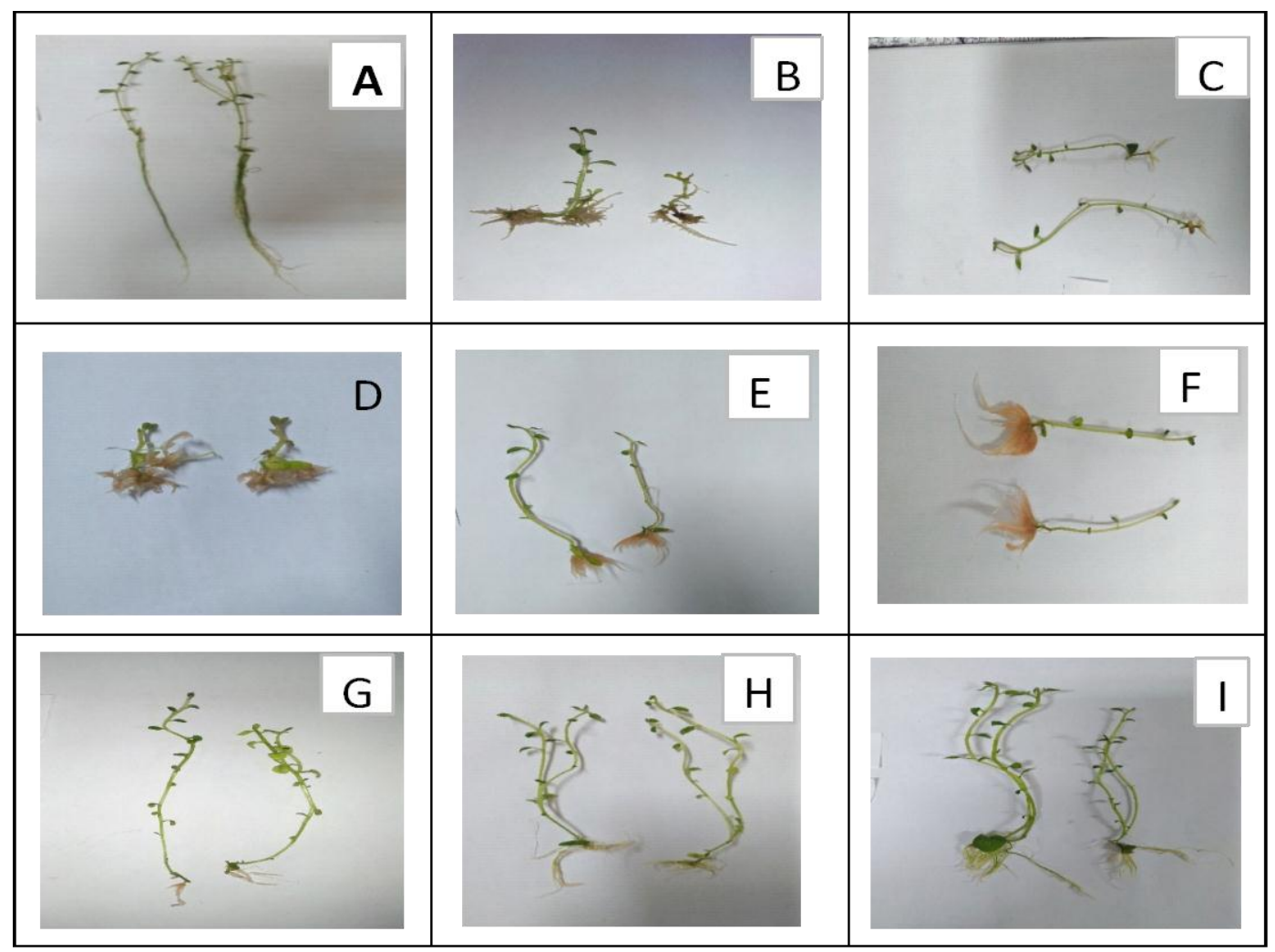

Gambar 3. Planlet kentang varietas Sangkuriang pada minggu ke 5 setelah subkultur. (A) Media MS 4,43 g/l, (B) Hyponex hijau 2 g/l, (C) Gandasil 2 g/l, (D) Hyponex hijau 2 g/l + vitamin B complex $0,1 \mathrm{mg} / \mathrm{l}$, (E) Hyponex hijau $2 \mathrm{~g} / 1+$ air kelapa $300 \mathrm{ml} / \mathrm{l}$, (F) Hyponex hijau $2 \mathrm{~g} / 1+$ vitamin B complex 0,1 mg/l + air kelapa $300 \mathrm{ml} / \mathrm{l},(\mathrm{G})$ Gandasil D $2 \mathrm{~g} / 1+$ vitamin B complex 0,1 mg/l, $(\mathrm{H})$ Gandasil D $2 \mathrm{~g} / \mathrm{l}+$ air kelapa $300 \mathrm{ml} / \mathrm{l}$, (I) Gandasil D $2 \mathrm{~g} / 1+$ vitamin B complex 0,1 mg/l + air kelapa $300 \mathrm{ml} / \mathrm{l}$. (Dokumen pribadi. Balitsa.2018)

Tabel 6. Pengaruh Formula Pupuk Majemuk Yang Berbeda Terhadap Vigor Planlet Pada Minggu Ke 5 Setelah Subkultur.

\begin{tabular}{|c|c|c|c|}
\hline & Perlakuan & $\begin{array}{c}\text { Nilai } \\
\text { rata-rata }\end{array}$ & Vigor \\
\hline$A=$ & Media MS 4,43 g/1 & 9,00 & Sangat baik \\
\hline $\mathrm{B}=$ & Hyponex hijau $2 \mathrm{~g} / 1$ & 2,33 & Sangat buruk \\
\hline $\mathrm{C}=$ & Gandasil D $2 \mathrm{~g} / 1$ & 5,23 & Sedang \\
\hline $\begin{array}{l}\mathrm{D} \\
=\end{array}$ & Hyponex hijau $2 \mathrm{~g} / 1+$ vitamin B complex $0,1 \mathrm{mg} / 1$ & 2,77 & Buruk \\
\hline $\mathrm{E}=$ & Hyponex hijau $2 \mathrm{~g} / 1+$ air kelapa $300 \mathrm{ml} / 1$ & 5,00 & Sedang \\
\hline $\mathrm{F}=$ & $\begin{array}{l}\text { Hyponex hijau } 2 \mathrm{~g} / 1+\text { vitamin B complex } 0,1 \mathrm{mg} / 1+\text { air } \\
\text { kelapa } 300 \mathrm{ml} / 1\end{array}$ & 5,00 & Sedang \\
\hline $\begin{array}{l}\text { G } \\
=\end{array}$ & Gandasil D $2 \mathrm{~g} / 1$ + vitamin B complex 0,1 mg/1 & 6,10 & Sedang \\
\hline $\begin{array}{l}\mathrm{H} \\
=\end{array}$ & Gandasil D $2 \mathrm{~g} / \mathrm{l}+$ air kelapa $300 \mathrm{ml} / 1$ & 8,77 & Sangat baik \\
\hline $\mathrm{I}=$ & $\begin{array}{l}\text { Gandasil D } 2 \mathrm{~g} / 1 \text { + vitamin B complex } 0,1 \mathrm{mg} / 1+\text { air } \\
\text { kelapa } 300 \mathrm{ml} / 1\end{array}$ & 8,77 & Sangat baik \\
\hline
\end{tabular}


Berdasarkan Tabel 6 dan Gambar 3, menunjukan bahwa perlakuan $\mathrm{A}=$ Media MS 4,43 g/l (9.00), H = Gandasil D $2 \mathrm{~g} / 1+$ air kelapa $300 \mathrm{ml} / 1$ (8,77) dan I $=$ Gandasil D $2 \mathrm{~g} / 1+$ vitamin B complex 0,1 mg/1 + air kelapa $300 \mathrm{ml} / 1$ (8.77) mempunyai vigor yang sangat baik, dan vigor sangat buruk ada pada perlakuan B $=$ Hyponex hijau $2 \mathrm{~g} / 1$. Perbedaan pertumbuhan ini dapat disebabkan karena adanya perbedaan formula pupuk majemuk, yang mengakibatkan perbedaan asupan unsur hara yang diserap oleh planlet, sehingga berpengaruh terhadap vigor planlet.

\section{KESIMPULAN}

1.

ormula pupuk majemuk yang berbeda berpengaruh terhadap pertumbuhan kultur invitro kentang (Solanum tuberosum L.) varietas Sangkuriang.

2.

ternatif formula pupuk majemuk pengganti media MS pertama ada pada perlakuan media $\mathrm{I}=$ Gandasil $\mathrm{D} 2$ gram/1 + vitamin B complex 0,1 mg/1 + air kelapa $300 \mathrm{ml} / \mathrm{l}$ dan alternatif formula kedua yaitu pada perlakuan $\mathrm{H}$ = Gandasil D 2 gram $/ 1$ + air kelapa $300 \mathrm{ml} / 1$, dengan demikian perlakuan I dan $H$ berpeluang baik terhadap pertumbuhan planlet karena telah mencapai keseimbangan formula untuk varietas Sangkuriang.

\section{DAFTAR PUSTAKA}

Badan Pusat Statistik. 2016. Produksi kentang nasional dari tahun 2014 2016. BPS. Jakarta.

Chris, Sugihono dan Agus Hasbianto. (2014). Perkembangan Penggunaan Teknik Kultur Jaringan Pada Tanaman Kentang (Solanum tuberosum L.) Prosiding Seminar
Nasional "Inovasi Teknologi

Pertanian Spesifik Lokasi”,

Banjarbaru 6-7 Agustus 2014 | 435.

Darlina,Hasanuddin, Hafnati Rahmatan. 2016. Pengaruh Penyiraman Air Kelapa (Cocos nucifera L.) Terhadap Pertumbuhan Vegetatif Lada (PIPER NIGRUML.)Jurnal Ilmiah Mahasiswa Pendidikan Biologi, Volume 1,Prodi Pendidikan Biologi, FKIP Unsyiah.

Nadapdap, Christmas. 2000. Penggunaan Pupuk Komersial Dan Air Kelapa Sebagai Media Perbanyakan In Vitro Tanaman Kentang (Solanum tuberosum L.) Skripsi. Jurusan Budidaya Pertanian. Fakultas Pertanian, IPB Bogor.

Prabaningrum, Laksminiwati, Tonny $\mathbb{K}$ Moekasan, Ineu Sulastrini, Tri Handayani, Juniarti P. Sahat, Eri Sofiari dan Nikardi Gunadi. 2014. Teknologi Budidaya Kentang di Dataran Medium. Monogralfi no.34. Balitsa.

Santoso, U dan F. Nursandi. 2003. Kultur Jaringan Tanaman Universitas Muhammadiyah Malang Press. Malang.

Shintiavira, Rahmawati I, dan Winarto, B. 2014. Aplikasi Modifikasi Media Generik Dalam Produksi Bibit Krisan (Dendranthema grandiflora Tzvelev) Berkualitas Melalui Kultur In Vitro. J. Hort. 24(3):220229. Balai Penelitian Tanaman Hias, Jl. Raya Ciherang Pacet, Cianjur.

Steel, R. G. D. dan J. H. Torrie. 1991. Prinsip dan Prosedur Statistika (suatu pendekatan biometrik). Diterjemahkan oleh Bambang Sumantri. PT. Gramedia Pustaka Utama. Jakarta.

Zulkarnain. 2009. Solusi Perbanyakan Tanaman Budidaya. Kultur Jaringan Tanaman. Bumi Aksara. 